\title{
PENGARUH PEMBERIAN EKSTRAK ETANOL HERBA BANDOTAN (Ageratum conyzoides) TERHADAP PENURUNAN KADAR KOLESTEROL TOTAL DAN TRIGLISERIDA PADA MENCIT (Mus musculus) HIPERLIPIDEMIA
}

\author{
Indah Puspita $^{1}$, Fakhruddin $^{2}$, Yogie Irawan $^{3}$ \\ ${ }^{1,2,3}$ STIKES Borneo Cendekia Medika Pangkalan Bun \\ Email Korespodensi : indahpita22@gmail.com
}

ABSTRAK

\begin{abstract}
Pendahuluan: Hiperlipidemia merupakan suatu keadaan patologis yang disebabkan oleh kelainan dari metabolisme lipid darah yang umumnya ditandai dengan meningkatnya kadar trigliserida, kolesterol total, Low Density Lipoprotein (LDL) serta penurunan kadar High Density Lipoprotein (HDL)

Metode: Penelitian ini menggunakan mencit putih jantan sebanyak 20 ekor yang terlebih dahulu diinduksi propiltiurasil dan diet pakan tinggi lemak. Pengujian terdiri dari 5 kelompok, yaitu kelompok kontrol positif (simvastatin 1,3 gr/kgBB), kelompok kontrol negatif ( $\mathrm{Na} \mathrm{CMC} 0.5 \%$ ) dan kelompok perlakuan dengan pemberian ekstrak etanol herba bandotan dengan dosis $0,5 \mathrm{gr} / \mathrm{kgBB} ; 1,5 \mathrm{gr} / \mathrm{kgBB}$ dan $2 \mathrm{gr} / \mathrm{kgBB}$ melalui oral selama 14 hari.
\end{abstract}

Hasil: Hasil uji statistika ANOVA menyatakan terdapat pengaruh Herba Bandotan dalam menurunkan kadar kolesterol total dan trigliserida yang sebanding dengan kontrol positif dengan hasil ( $\mathrm{p}<0,05)$. Kemudian pada uji LSD menyatakan kelompok perlakuan dengan dosis 2 gr/kgBB memiliki kemampuan paling baik diantara kelompok perlakuan dosis ekstrak lainnya

Kesimpulan: Terdapat pengaruh pemberian ekstrak etanol herba bandotan (Ageratum conyzoides) terhadap penurunan kadar kolesterol total dan trigliserida pada mencit hiperlipidemia

Kata Kunci: Herba bandotan (Ageratum conyzoides), hiperlipidemia, kolesterol total, trigliserida,

\begin{abstract}
Introduction: Hyperlipidemia is a pathological condition caused by a disorder of blood lipid metabolism which is generally characterized by increased levels of triglycerides, total cholesterol, Low Density Lipoprotein (LDL) and decreased levels of High Density Lipoprotein (HDL).

Methods: This study used 20 male white mices that were induced propylthiouracil and had a high-fat feed diet. The test consisted of 5 groups; positive control group (simvastatin $1.3 \mathrm{~g} / \mathrm{kgBW}$ ), negative control group $(0.5 \%$ $\mathrm{Na} \mathrm{CMC}$ ) and treatment groups that given the ethanol extract of bandotan herb at a dose of $0.5 \mathrm{gr} / \mathrm{kgBW} ; 1.5 \mathrm{gr} / \mathrm{kgBW}$ and $2 \mathrm{~g} / \mathrm{kgBW}$ orally for 14 days.

Results: The results of the ANOVA statistical test indicated that there was an effect of bandotan herb in reducing the total cholesterol and triglyceride levels
\end{abstract}


which was comparable to the positive control with the results $(\mathrm{p}<0.05)$. Then in the LSD test, it was stated that the treatment group with a dose of $2 \mathrm{gr} / \mathrm{kgBW}$ had the best ability among the other extract dose treatment groups.

Conclusion: There was an effect of giving the ethanol extract of bandotan herb (Ageratum conyzoides) in reducing the total cholesterol and triglyceride levels in hyperlipidemia white mices.

Key words: Bandotan herbs (Ageratum conyzoides), hyperlipidemia, total cholesterol, triglycerides,

\section{PENDAHULUAN}

Penyakit degeneratif yang cukup banyak memengaruhi angka kematian adalah penyakit kardiovaskuler. Terjadinya penyakit jantung koroner (PJK) tidak lepas dari proses-proses yang meyebabkan pembuluh darah koroner menyempit. Kadar kolesterol yang tinggi merupakan $56 \%$ faktor yang berkontribusi besar dalam terjadinya PJK. Peningkatan kolesterol serum, terutama peningkatan LDL akan menciptakan kondisi hiperlipidemia yang meningkatkan resiko PJK (Yani, 2015).

Faktor resiko utama dari penyakit jantung korone (PJK) adalah hiperlipidemia. Hiperlipidemia adalah suatu kelainan bersifat heteregon yang umumnya ditandai dengan peningkatan kadar kolesterol total, low density lipoprotein (LDL), very low density lipoprotein (VLDL), terigliserida, dan penurunan kadar high density lipoprotein (HDL). Selain itu, hiperlipidemia juga dapat didefinisikan sebagai serum kolesterol minimal $200 \mathrm{mg} / \mathrm{dl}$ atau serum trigliserida minimal 150 mg/dl. (Putri,et al., 2016).

Masyarakat luas beranggapan bahwa penggunan tumbuhan berkhasiat lebih aman dibandingkan dengan obat kimia sehingga mereka lebih suka menggunakan obat tradisional untuk menyembuhkan penyakitnya (Rani, et al., 2019).

Herba bandotan (Ageratum conyzoides) merupakan tanaman liar yang memiliki potensi yang besar sebagai tanaman obat. Pada penelitian yang dilakukan oleh Egi Supriyadi bersama teman-temannya tahun 2014, ekstrak dari daun bandotan (Ageratum conyzoides) berhasil menurukan kadar total kolesterol darah pada ayam broiler, dimana kadar kolesterol total pada kelompok pemberian ekstrak daun bandotan adalah $113 \mathrm{mg} / \mathrm{dl}$ lebih rendah jika dibandingkan dengan kelompok kontrol negatif dengan kadar kolesterol total $134 \mathrm{mg} / \mathrm{dl}$ (Egi,et al., 2014).

Menurut penelitian yang dilakukan oleh Agbafor tahun 2015 daun dan akar tanaman bandotan diketahui mengandung senyawa alkaloid, flavonoid, tannin, saponin, glikosida jantung, antrakuion, mineral, vitamin serta senyawa lainya yang memiliki aktivitas farmakologi (Agbafor, et al., 2015). Secara khusus saponin, tanindan flavonoid dapat dimanfaatkan untuk menurukan aktivitas koleterol serum memiliki efek menurunkan kolesterol darah (Egi,et al., 2014). 


\section{METODE PENELITIAN}

\section{Alat dan Bahan}

Pada peelitian ini alat yang digunakan adalah Sonde oral, timbangan analitik, sentrifuse, tabung setrifuse, alat pengambil darah, rak tabung, tabung reaksi, beaker glass, gelas ukur, corong, labu takar, erlenmeyer, ayakan mesh, blender, spektrofotometer, UVvisible, kertas saring, batang pengaduk, morter dan stemper, kandang mencit beserta tempat pakan dan minum. Bahan-bahan yang digunakan Herba bandotan (Ageratum conyzoides), Simvastatin (Kimia Farma), Etanol 70\%, aquadest, $\mathrm{FeCl} 3, \mathrm{H} 2 \mathrm{SO} 4$, asam asetat anhidrat, Serbuk Mg, HCL, mencit putih jantan (Mus musculus),Propitilurasil dan pakan tinggi lemak yang terdiri dari campuran kuning puyuh, minyak babi dan minyak jelantah,

\section{Cara kerja \\ Pengumpulan dan Pengolahan Simplisia Herba Bandotan}

Pengumpulan sampel

dilakukan secara acak, sampel yang diambil berupa seluruh bagian dari tanaman bandotan (herba) yang masih segar dan berwarna hijau yang diambil dari lingkungan Jl. Jendral Sudirman, Karang Anyar, Pangkalan Bun, Kabupaten Kotawaringin Barat,Kalteng. Simplisia segar yang telah dikumpulkan selanjutnya akan melalui beberapa proses yang meliputi sortasi basah, pencucian, penimbangan, pengeringan dengan cara diangin-anginkan

\section{Pembuatan Ekstrak}

Sampel diserbukkan dan diperoleh bobot kering sebanyak 1120 gram yang kemudian dimaserasi dengan menggunakan penyari etanol dengan perbandingan 1:5. Maserasi dilakukan selama 5 hari dan dilakukan pengadukan secara berkala. Filtrat yang diperoleh selanjutnya dipekatkan dengan menggunakan waterbath pada suhu tidak lebih dari $60^{\circ} \mathrm{C}$ hingga diperoleh ekstrak kental.

\section{Skrining Fitokimia Dengan Reagen}

1. Flavonoid

Ekstrak dicampur dengan 3 $\mathrm{ml}$ etanol $70 \%$ lalu dikocok, dipanskan dan dikocok lgi kemudian disaring. Filtrat yang diperoleh ditambahkan serbuk Mg 0,1 gram dan 2 tetes $\mathrm{HCl}$ pekat, terbentuknya warna merah pada lapisan etanol menunjukkan adanya flavonoid (Yuri, et al., 2017).

2. Saponin

Pengidentikasian dari senyawa saponin adalah dengan memanfaatkan sifatnya tersebut. Identifikasi saponin dapat dilakukan dengan cara mengocok ekstrak yang telah ditambahkan dengan $10 \mathrm{ml}$ air panas didalam tabung reaksi, indikasi senyawa saponin akan membentuk busa setelah dikocok yang dapat bertahan lama (tidak hilang selama 30 detik) (Ani, 2015).

3. Tanin

Ekstrak disari denga $10 \mathrm{ml}$ air kemudian disaring filtratnya diencerkan dengan air sampai tidak berwarna. Larutan diambil $2 \mathrm{ml}$ dan ditambahkan 2 tetes $\mathrm{FeCl} 1 \%$. Terbentuknya warna cokelat kehijauan menunjukkan adanya Tanin (Yuri, et al., 2017). 


\section{Skrining Fitokimia Dengan Kromatografi Lapis Tipis}

1. Flavonoid

Penyiapan fase diam plat silica gel G60 F254 dengan ukuran 8 $\mathrm{cm}$ x $2 \mathrm{~cm}$, kemudian lempeng dicuci dengan metanol, lalu diaktivasi dengan oven pada suhu $100^{\circ} \mathrm{C}$ selama 10 menit. Sebanyak $10 \mathrm{mg}$ ekstrak dilarutkan dalam $1 \mathrm{ml}$ etanol kemudian ditotolkan pada fase diam. Fase gerak berupa campuran asam setat glacial : butanol : air dengan perbandingan 1:4:5, dengan penampak noda uap amonia. Reaksi positif ditandai degan warna kuning coklat pada pengamatan sinar tampak UV 366 nm (Maliana, 2012).

2. Saponin

Lempeng alumunium silica gel GF254 Merck disiapkan dengan ukuran $10 \mathrm{~cm}$ x $3 \mathrm{~cm}$. Ekstrak kental yang telah dilarutkn dengan alkohol 95\% ditotolkan pada lempeng lalu dimasukkan kedalam Chamber yang berisi eluen yaitu campuran kloroform : metanol : aquades (13:7:2).Pengamatan noda dapat menggunakan lampu UV 254 dan 366 nm. (Pratama, et al., 2012).

3. Tanin

Plat silica gel G60 F254 dengan ukuran $8 \mathrm{~cm}$ x $2 \mathrm{~cm}$ dicuci dengan metanol, lalu diaktivasi dengan oven pada suhu $100^{\circ} \mathrm{C}$ selama 10 menit. Fase gerak berupa campuran metanol : air dengan pebandingan 6:4, dengan penampak noda pereaksi $\mathrm{FeCl} 35 \%$. Reaki positif ditujukkan dengan terbentuknya warna hitam (Banu dan Nagarajan, 2014).

\section{Persiapan Hewan Uji}

Hewan uji yang digunakan dalam penelitian ini adalah mencit jantan (Mus musculus) dengan berat badan 25 - 30 gram sebanyak 20ekor. Sebelum penelitian hewan uji diadaptasikan selama tujuh hari untuk membiasakan pada makanan, minuman dan lingkungan percobaan.

\section{Induksi Hiperlipidemia}

Pakan tinggi lemak yang diberikan pada hewan uji terdiri dari campuran kuning telur puyuh, minyak babi dan minyak jelantah dengan perbandingan 3:2:1. Selain pakan tinggi lemak, hewan uji juga diinduksi dengan propitilurasil untuk mempercepat pencapaian kondisi hiperlipidemia. Pakan tinggi lemak diberikan dua kali sehari pagi dan sore selama 14 hari, sedangkan induksi PTU diberikan satu kali sehari di pagi hari secara oral selama 14 hari.

\section{Uji Pengaruh Antihiperlipidemia}

Sebanyak 20 ekor mencit putih jantan yang mengalami hiperlipidemia dibagi menjadi 5 kelompok dengan perlakuan yang berbeda setiap kelompoknya adapun perlakuan tersebut yaitu:

Kelompok I kontrol positif : Perlakuan 1,3gr/ kg BB/hari larutan simvastatin $10 \mathrm{mg}$. Kelompok II kontrol negatif : Perlakuan larutan CMC 0,5\%. Kelompok III kelompok perlakuan I : Perlakuan ekstrak etanol herba bandotan (Ageratum conyzoides) 0,5gr/ $\mathrm{kg} \quad \mathrm{BB}$. Kelompok IV kelompok perlakuan I : Perlakuan ekstrak etanol herba bandotan (Ageratum conyzoides) $1,5 \mathrm{gr} / \mathrm{kg}$ BB. Kelompok V kelompok perlakuan I : Perlakuan ekstrak etanol herba bandotan (Ageratum conyzoides) $2 \mathrm{gr} / \mathrm{kg} \mathrm{BB}$ 
Pengukuran Kadar Kolesterol Total dan Trigliserida Hewan Uji.

Pengambilan darah hewan uji dilakukan dengan metode facial vein atau melalui pembuluh darah pada wajah hewan uji. Pengukuran kadar kolesterol total dan trigliserida mencit dilakukan sebelum perlakuan (hari ke-0), setelah induksi (hari ke14) dan setelah pemberian larutan uji (hari ke-28). Pengambilan sampel darah dilakukan melalui sinus orbitalis yaitu mata dari hewan uji. Kemudian sampel darah akan diuji di laboratorium kesehatan daerah Pangkalan Bun.

\section{Analisa Data}

Analisa data yang digunakan dalam penelitian ini yaitu metode One-way Analysis of Variance (ANOVA) dengan perangkat lunak Statistical Package For Social Science (SPSS), dengan taraf kepercayaan $95 \%$ untuk meganalisis kadar kolesterol total dan trigliserida dengan variasi dosis ekstrak untuk masing-masing perlakuan.

\section{HASIL DAN PEMBAHASAN \\ Skrining Fitokimia Menggunakan Reagen dan KLT}

Hasil uji fitokimia ekstrak herba bandotan (Ageratum conyzoides) menggunakan reagen dapat dilihat pada tabel 1 . Sedangkan hasil uji fitokimia ekstrak herba bandotan (Ageratum conyzoides) dengan menggunakan kromatografi lapis tipis dapat dilihat pada tabel 2.

Dari hasil uji fitokimia ekstrak ekstrak herba bandotan (Ageratum conyzoides) menggunakan reagen pada Tabel 1 dapat diketahui bahwa ekstrak tanaman putri malu positif mengandung senyawa flavonoid, saponin dan tanin.

Tabel 1. Hasil Skrining Fitokimia Ekstrak Herba Bandotan (Ageratum conyzoides)

\begin{tabular}{|c|c|c|}
\hline Perlakuan & Hasil & Kesimpulan \\
\hline $\begin{array}{l}\text { Uji Flavonoid } \\
\text { Sampel }+\mathrm{Mg} \\
0,1 \text { gram }+2 \\
\text { tetes } \mathrm{HCl} \\
\text { (Yuri, et al., } \\
\text { 2017). }\end{array}$ & $\begin{array}{c}\text { Terbentuk } \\
\text { endapan } \\
\text { jingga } \\
\text { kemerahan }\end{array}$ & + \\
\hline $\begin{array}{c}\text { Uji Saponin } \\
\text { Sampel + } 10 \\
\text { ml air panas } \\
\text { dikocok (Ani, } \\
\text { 2015). }\end{array}$ & $\begin{array}{c}\text { Terbentuk } \\
\text { busa stabil } \\
\text { setinggi } \\
5 \mathrm{~cm}\end{array}$ & + \\
\hline $\begin{array}{c}\text { Uji Tanin } \\
2 \mathrm{ml} \text { sampel + } \\
2 \text { tetes FeCl } \\
1 \% \text {. (Yuri, et } \\
\text { al., 2017). }\end{array}$ & $\begin{array}{l}\text { Terbentuk } \\
\text { endapat } \\
\text { coklat } \\
\text { kehitaman }\end{array}$ & + \\
\hline
\end{tabular}

Sedangkan uji fitokimia ekstrak herba bandotan (Ageratum conyzoides) dengan menggunkan kromatografi lapis tipis pada Tabel 2 juga diketahui bahwa ekstrak tanaman herba bandotan positif mengandung senyawa flavonoid, saponin dan tanin.

Tabel 2. Hasil Skrining Fitokimia Ekstrak Herba Bandotan (Ageratum conyzoides) Menggunakan KLT

\begin{tabular}{ccc} 
Perlakuan & Keterangan & Kesimpulan \\
\hline Uji & & \\
Flavonoid & & \\
Asetat & \\
glacial: & Berwarna & \\
butanol: air & kuning & \\
(1:4:5), & setelah & $(+)$ \\
penampak & diuapi & \\
noda uap & amoniak. & \\
amoniak. & \\
(Maliana, & \\
2012). & \\
\hline
\end{tabular}




\begin{tabular}{|c|c|c|}
\hline Uji & & \\
Saponin \\
kloroform: \\
metanol: & terdapat & \\
aquades & bercak & \\
$(13: 7: 2)$. & merah coklat & $(+)$ \\
(Pratama, &. & \\
et al., & \\
2012). & & \\
Uji Tanin & \\
Metanol: & \\
air (6:4), & terbentuk \\
pereaksi & noda & \\
FeC13 5\%. & berwarna \\
(Banu dan & hitam. \\
Nagarajan, & \\
2014). & \\
\hline
\end{tabular}

Flavonoid memiliki mekanisme mencegah enzim HMGCoA reduktase sehingga sintesis kolesterol menurun sehingga mengakibatkan kadar kolesterol dalam darah menurun. Selain itu flavonoid dapat menghambat penyerapan kolesterol dari makanan sehigga tidak terjadi peningkatkan kolesterol dalam darah hewan uji (Susiwati,2018). Flavonoid dapat menurunkan kadar kolesterol total dengan cara menghambat 3Hydroxy-3Methyl- GlutarylCoenzymeA reduktase yang menyebabkan penurunan sintesis kolesterol dan meningkatkan jumlah reseptor LDL yang terdapat di dalam membran sel hepar dan jaringan ekstrahepatik sehingga kadar kolesterol total akan menurun, dengan penurunan kadar kolesterol total tersebut maka LDL yang berfugsi sebagai alat pengangkut lipid didalam darah akan berkurang (Sri mutia et al.,2018).

Saponin dapat membentuk suatu ikatan kompleks dengan kolesterol dari makanan yang tidak dapat larut di dalam usus, sehingga kolesterol tersebut tidak dapat diserap. Saponin dan kolesterol yang terikat dapat keluar dari saluran cerna. Hal ini dapat menyebabkan kolesterol dalam tubuh dapat berkurang (Ani,2015).

Senyawa antioksidan lainnya yang dapat menurunkan kadar kolesterol didalam darah adalah tanin. Berdasarkan penelitian yang dilakukan oleh Agustina pada tahun 2013, senyawa tanin dapat menghambat aktivitas HMG-CoA reduktase yang menyebabkan penurunan sintesis kolesterol di hati sehingga menurunkan sintesis Apo B-100 (Apolipoprotein yang terkandung di dalam VLDL). dan meningkatkan reseptor LDL dipermukaan hati, sehingga kolesterol LDL darah akan ditarik ke hati dan menurunkan kadar LDL dan VLDL (Sri mutia et al.,2018). Tanin dapat bereaksi dengan enzim mukosa dan sel epitel usus. Enzim tersebut akan berikatan dengan tanin yang mengakibatkan enzim mengendap di permukaan usus, sehingga penyerapan makanan yang mengandung lemak akan terhambat

\section{Pengaruh Pemberian Ekstrak Herba Bandotan (Ageratum conyzoides) Terhadap Penurunan Kadar Kolesterol Total dan Trigliserida}

Penilaian pengaruh anti hiperlipidemia ekstrak herba bandotan pada penelitian ini didasarkan pada dua parameter yaitu kadar total kolesterol dan kadar trigliserida. Dalam penelitian ini digunakan 20 ekor mencit jantan yang dibagi menjadi 5 kelompok perlakuan. Kelompok + : diberi simvastatin, kelompok - : diberi $\mathrm{Na}$ CMC, kelompok I : diberi ekstrak 
herba bandotan dosis I, kelompok II : diberi ekstrak herba bandotan dosis II dan kelompok III : diberi ekstrak herba bandotan dosis III.

Sebelum menerima perlakuan semua kelompok hewan uji dikondisikan hiperlipidemia melalui agen penginduksi hiperlipidemia dengan metode eksogen dan endogen. Metode eksogen dilakukan dengan pemberian pakan tinggi lemak, sedangkan secara endogen diberikan propitilurasil. Pemberian induksi hiperlipidemia ini dilakukan selama 14 hari dari hari ke-1 hingga

Tabel 3. Hasil Pengukuran Kadar Kolesterol Total (mg/dl) serta Persen Kenaikan dan Persen Penurunan Semua Kelompok Perlakuan

\begin{tabular}{|c|c|c|c|c|c|c|}
\hline \multirow{2}{*}{\multicolumn{2}{|c|}{ Kelompok }} & $\frac{\text { Hari ke-0 }}{\mathbf{y}}$ & $\frac{\text { Hari ke-14 }}{\mathrm{Y}}$ & $\begin{array}{c}\text { \% Rerata } \\
\text { kenaikan }\end{array}$ & $\begin{array}{c}\text { Hari ke-28 } \\
\mathbf{Y}\end{array}$ & $\begin{array}{c}\% \text { Rerata } \\
\text { penurunan }\end{array}$ \\
\hline & & $\begin{array}{c}\mathbf{X} \\
\pm \mathrm{SD}\end{array}$ & $\begin{array}{c}\mathbf{X} \\
\pm \mathrm{SD}\end{array}$ & $\begin{array}{c}\mathrm{X} \\
\pm \mathrm{SD}\end{array}$ & $\begin{array}{c}\mathbf{X} \\
\pm \mathrm{SD}\end{array}$ & $\begin{array}{c}\mathrm{X} \\
\pm \mathrm{SD}\end{array}$ \\
\hline $\begin{array}{c}\text { Kontrol Positif (Simvastatin } \\
\text { (kgBB) }\end{array}$ & $0,026 \mathrm{~g} / 20$ & $\begin{array}{c}120,25 \\
\pm 3,2\end{array}$ & $\begin{array}{r}155,5 \\
\pm 11,1\end{array}$ & $\begin{array}{c}30 \\
\pm 12\end{array}$ & $\begin{array}{l}97,75 \\
\pm 8,54\end{array}$ & $\begin{array}{l}37 \\
\pm 7^{\text {a }}\end{array}$ \\
\hline $\begin{array}{c}\text { Kontrol negatif } \\
\text { CMC } 0.5 \%\end{array}$ & & $\begin{array}{l}123,25 \\
\pm 5,67\end{array}$ & $\begin{array}{c}154 \\
\pm 5,09\end{array}$ & $\begin{array}{l}25 \\
\pm 5\end{array}$ & $\begin{array}{l}157,25 \\
\pm 6,89\end{array}$ & $\begin{array}{c}2 \\
\pm 5\end{array}$ \\
\hline $\begin{array}{r}\text { Ekstrak Herba Bandotan } \\
(0,01 / 20 \text { gr BB })\end{array}$ & Dosis I & $\begin{array}{l}122,25 \\
\pm 5,85\end{array}$ & $\begin{array}{l}157,25 \\
\pm 10,21\end{array}$ & $\begin{array}{l}29 \\
\pm 6\end{array}$ & $\begin{array}{l}110,75 \\
\pm 6,65\end{array}$ & $\begin{array}{l}29 \\
\pm 4^{\mathrm{a}}\end{array}$ \\
\hline $\begin{array}{r}\text { Ekstrak Herba Bandotan } \\
(0,03 / 20 \text { gr BB })\end{array}$ & Dosis II & $\begin{array}{c}115,75 \pm \\
11,52\end{array}$ & $\begin{array}{c}167 \\
\pm 5,41\end{array}$ & $\begin{array}{c}46 \\
\pm 17\end{array}$ & $\begin{array}{c}113 \\
\pm 4,69\end{array}$ & $\begin{array}{l}32 \\
\pm 3^{\mathrm{ab}}\end{array}$ \\
\hline $\begin{array}{l}\text { Ekstrak Herba Bando } \\
\text { Dosis III }(0,04 / 20 \text { gr }\end{array}$ & $\begin{array}{l}\tan \\
\mathrm{BB}\end{array}$ & $\begin{array}{l}123,25 \\
\pm 3,77\end{array}$ & $\begin{array}{l}166,75 \\
\pm 4,78\end{array}$ & $\begin{array}{l}35 \\
\pm 7\end{array}$ & $\begin{array}{l}108,5 \\
\pm 6,85\end{array}$ & $\begin{array}{c}35 \\
\pm 4^{\mathrm{ab}}\end{array}$ \\
\hline
\end{tabular}

Keterangan:
a
ada perbedaan dengan kontrol negatif dengan uji $L S D$ one way anova.
tidak ada perbedaan dengan kontrol positif dengan LSD one way

b : anova.

Kadar kolesterol total pada semua kelompok mengalami kenaikan pada hari ke-14 dibandingkan hari ke-0 dan mengalami penurunan pada hari ke28 dibandingkan hari ke-14. Hasil penurunan kadar kolesterol total dapat diketahui melalui perhitungan dari kadar kolesterol total setelah diinduksi dikurangi dengan kadar hari ke-14 setelah dilakukan pengambilan sampel darah pada hari ke-0.

Pengambilan sampel darah pada hewan uji dilakukan sebanyak 3 kali yaitu pada hari ke-0 (sebelum diberikan induksi hiperlipidemia), hari ke-14 (setelah 14 hari induksi hiperlipidemia) dan hari ke-28 (setelah 14 hari perlakuan). Pengambilan sampel darah dilakukan melalui vena facialis pada daerah submandibular mencit sebanyak 5-10 tetes disetiap pengambilannya. 
Penurunan kadar kolesterol total diatas terdapat perbedaan secara signifikan antara hari ke-14 setelah pemberian induksi hiperlipidemia dan hari ke-28 setelah perlakuan pada seluruh kelompok hewan uji selama 14 hari. Terdapat penurunan secara signifikan dari pemberian dosis II dan dosis III ekstrak herba bandotan terhadap penurunan kadar kolesterol total hewan uji.

Berdasarkan interpretasi data dari uji Anova pada tabel 4 menunjukkan nilai $\mathrm{F}$ hitung sebesar 32,739 (tabel 5.9) > F tabel 3,06 dan nilai signifikan $0,000<0,05$ dengan demikian dapat disimpulkan bahwa $\mathrm{H}_{0}$ ditolak, atau hipotesis diterima yakni terdapat pengaruh pemberian ekstrak herba bandotan terhadap penurunan kadar kolesterol total mencit

Tabel 4. Hasil Uji One Way Anova Penurunan Kadar Kolesterol Total

ANOVA

Penurunan_kolesterol

\begin{tabular}{|l|r|r|r|r|r|}
\hline & \multicolumn{1}{|c|}{$\begin{array}{c}\text { Sum of } \\
\text { Squares }\end{array}$} & \multicolumn{1}{c|}{ df } & Mean Square & F & Sig. \\
\hline Between Groups & 3601,300 & 4 & 900,325 & 32,739 &, 000 \\
Within Groups & 412,500 & 15 & 27,500 & & \\
Total & 4013,800 & 19 & & & \\
\hline
\end{tabular}

Pada tabel 5 analisa Post Hoc LSD menyatakan adanya perbedaan yang signifikan antara kelompok ekstrak herba bandotan baik dosis I, II dan III dengan kelompok kontrol negatif dengan nilai signifikasi 0,000 $(p<0,05)$ yang artinya berbeda signifikan antara mencit yang diberi placebo dengan mencit yang diberi ekstrak herba bandotan dosis I, II dan III, sedangkan tidak ada perbedaan yang signifikan antara kelompok kontrol positif dengan ekstrak herba bandotan dosis II dan III $(p>0,05)$ berturut-turut 0,395 dan 0,470 yang artinya ekstrak herba bandotan dosis II dan III memiliki potensi untuk menurunkan kadar kolesterol total pada mencit hiperkolesterolemia yang sebanding dengan obat simvastatin.

Dari ke-2 dosis ekstrak herba bandotan yang memberikan pegaruh terhadap penurunan kadar kolesterol total yaitu dosis II dan III, dosis III memiliki pengaruh dalam menurunkan kadar kolesterol total yang paling sebanding dengan kontrol positif hal ini dapat dilihat dari nilai signifikannya tehadap kontrol positif yang paling besar yaitu 0,470 .

Tabel 5. Hasil Uji Post Hoc LSD Persen Penurunan Kadar Kolesterol

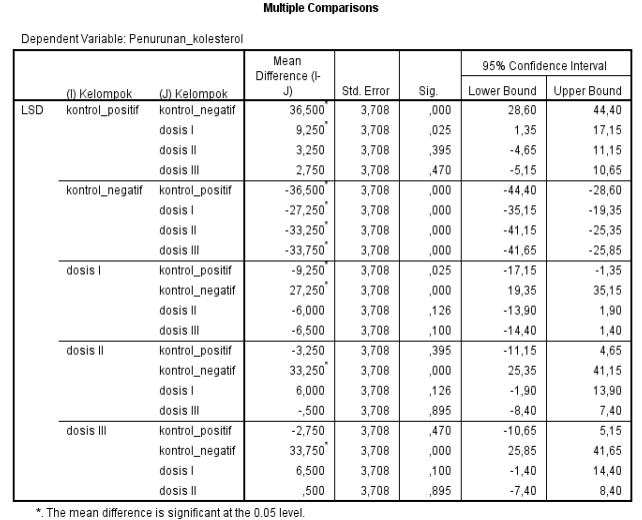

Sama halnya pada pengujian kadar trigliserida pada semua kelompok mengalami kenaikan pada hari ke-14 dibandingkan hari ke-0 dan mengalami penurunan pada hari ke-28 dibandingkan hari ke-14. Hasil penurunan kadar trigliserida dapat diketahui melalui perhitungan dari kadar trigliserida setelah diinduksi dikurangi dengan kadar trigliserida setelah perlakuan. Kemudian dihitung reratanya seperti yang tertera pada Tabel 6 
Tabel 6. Hasil Pengukuran Kadar Trigliserida serta Persen Kenaikan dan Persen Penurunan Semua Kelompok Perlakuan

\begin{tabular}{|c|c|c|c|c|c|}
\hline \multirow{2}{*}{ Kelompok } & Hari ke-0 & Hari ke-14 & $\begin{array}{l}\text { \% Rerata } \\
\text { kenaikan }\end{array}$ & Hari ke-28 & $\begin{array}{c}\text { \% Rerata } \\
\text { penurunan }\end{array}$ \\
\hline & $\begin{aligned} & X \\
& \pm \text { SD } \\
&\end{aligned}$ & $\begin{aligned} & X \\
& \pm \text { SD } \\
&\end{aligned}$ & $\begin{aligned} & X \\
& \pm \text { SD } \\
&\end{aligned}$ & $\begin{aligned} & X \\
& \pm \text { SD } \\
&\end{aligned}$ & $\begin{aligned} & X \\
& \pm \text { SD } \\
&\end{aligned}$ \\
\hline \multirow{2}{*}{$\begin{array}{l}\text { Kontrol Positif (Simvastatin } \\
0,026 \mathrm{~g} / 20 \mathrm{kgBB})\end{array}$} & 119,5 & 193,5 & 63 & 129,75 & 33 \\
\hline & $\pm 10,53$ & $\pm 9,03$ & \pm 12 & $\pm 2,5$ & $\pm 3^{\mathrm{a}}$ \\
\hline \multirow{2}{*}{$\begin{array}{c}\text { Kontrol negatif } \\
\text { CMC } 0.5 \%\end{array}$} & 120,5 & 191,75 & 60 & 189,5 & 1 \\
\hline & $\pm 8,54$ & $\pm 15,5$ & \pm 20 & $\pm 15,15$ & \pm 0 \\
\hline \multirow{2}{*}{$\begin{array}{l}\text { Ekstrak Herba Bandotan Dosis I } \\
\qquad(0,01 / 20 \text { gr BB })\end{array}$} & 120 & 182 & 53 & 141,25 & 22 \\
\hline & $\pm 1,73$ & $\pm 9,41$ & \pm 8 & $\pm 14,86$ & $\pm 6^{\mathrm{a}}$ \\
\hline \multirow{2}{*}{$\begin{array}{l}\text { Ekstrak Herba Bandotan Dosis II } \\
\qquad(0,03 / 20 \text { gr BB })\end{array}$} & & 179,5 & 46 & 127 & 29 \\
\hline & $\begin{array}{l}122,15 \\
\pm 4,57\end{array}$ & $\pm 12,39$ & \pm 10 & $\pm 3,46$ & $\pm 3^{\mathrm{a}}$ \\
\hline Ekstrak Herba Bandotan & 119 & 188,25 & 59 & 127,25 & 32 \\
\hline Dosis III $(0,04 / 20$ gr BB $)$ & $\pm 10,42$ & $\pm 10,87$ & \pm 15 & $\pm 2,06$ & $\pm 4^{\mathrm{ab}}$ \\
\hline
\end{tabular}

Keterangan:
a
ada perbedaan dengan kontrol negatif dengan uji $L S D$ one way anova.
tidak ada perbedaan dengan kontrol positif dengan LSD one way
b : anova.

Adapun grafik penurunan kadar trigliserida pada hewan uji terlihat pada Gambar 2 penurunan kadar trigliserida diatas terdapat perbedaan secara signifikan antara hari ke-14 setelah pemberian induksi hiperlipidemia dan hari ke-28 setelah perlakuan pada seluruh kelompok hewan uji selama 14 hari. Terdapat penurunan secara signifikan dari pemberian dosis III ekstrak herba bandotan terhadap penurunan kadar trigliserida hewan uji.

Gambar 2. Grafik Penurunan Kadar Trigliserida

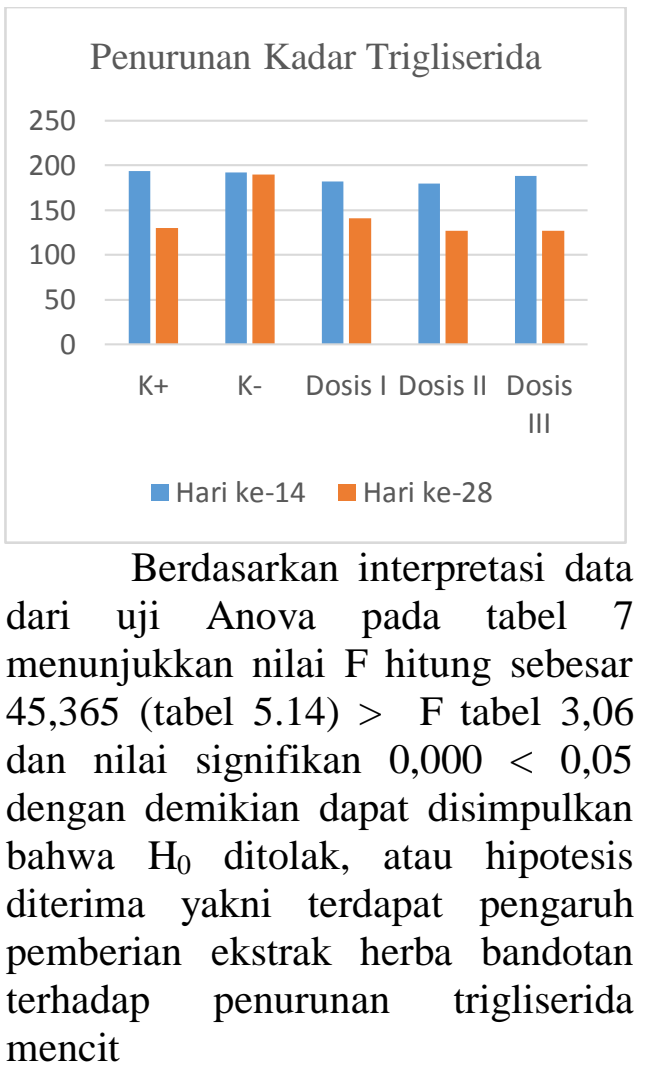

Tabel 7. Hasil Uji One Way Anova Penurunan Kadar Trigliserida 
ANOVA

penurunan_Tg
\begin{tabular}{|l|r|r|r|r|r|}
\hline & \multicolumn{1}{c|}{$\begin{array}{c}\text { Sum of } \\
\text { Squares }\end{array}$} & \multicolumn{1}{c|}{ df } & Mean Square & F & \multicolumn{1}{c|}{ Sig. } \\
\hline Between Groups & 3148,300 & 4 & 787,075 & 45,365 &, 000 \\
Within Groups & 260,250 & 15 & 17,350 & & \\
Total & 3408,550 & 19 & & & \\
\hline
\end{tabular}

Pada analisa Post Hoc LSD tabel 8 menyatakan tidak ada perbedaan yang signifikan antara kelompok kontrol positif dengan ekstrak herba bandotan dosis III $(p>0,05)$ yaitu 0,933 yang artinya ekstrak herba bandotan dosis III memiliki potensi untuk menurunkan kadar trigliserida mencit hiperlipidemia yang sebanding dengan obat simvastatin.

Dari ke-3 dosis ekstrak herba bandotan, dosis III memiliki pengaruh dalam menurunkan kadar trigliserida pada mencit hiperlipidemia.

Tabel 8. Hasil Uji Post Hoc LSD Persen Penurunan Kadar Trigliserida

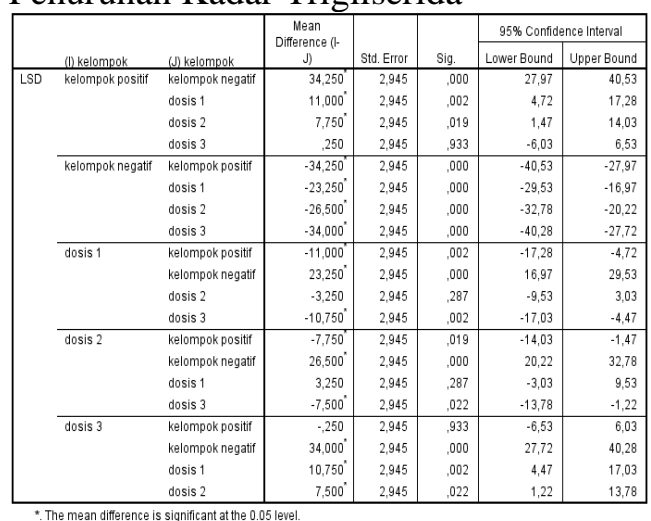

\section{KESIMPULAN}

Adanya pengaruh pemberian Ekstrak herba bandotan (Ageratum conyzoides) pada dosis III $(0,04 \mathrm{mg} /$ 20gramBB) dalam menurunkan kadar kolesterol total dan trigliserida pada mencit hiperlipidemia yang diinduksi PTU dan pemberian pakan tinggi lemak dengan persentase penurunan koleterol total $35 \%$ dan trigliserida $32 \%$.

\section{SARAN}

1. Perlu dilakukan penelitian lebih lanjut mengenai dosis ekstrak herba bandotan (Ageratum conyzoides) yang paling efektif sebagai agen antihiperlipidemia

2. Perlu dilakukan uji toksisitas pada ekstra herba bandotan (Ageratum conyzoides)

3. Perlu dilakukan penelitian lebih lanjut dengan membuat fraksi dari ekstra herba bandotan (Ageratum conyzoides) untuk mengtahui senyawa anti hiperlipidemia secara spesifik

\section{DAFTAR PUSTAKA}

Ani, K. 2015. Uji Efek Antihiperlipidemia Ekstrak Etanol Buah Parijoto Parijoto (Mediinilla speciosa Blume) Terhadap Kolesterol Total, Trigliserida dan VLDL Pada Tikus Putih Jantan. Fakultas Kedokteran dan Ilmu Kesehatan Program Studi Farmasi UIN Syarif Hidayatullah. Jakarta.

Taufiq, H., dan Alfien, S. 2018. The Effect of Hypothyroidisme on the Body Weight and Food Intake of Male Wistar Rats. Balai Litbang Kesehatan Magelang. Magelang.

Tri, W., Sri, K.W., dan Nyoman, S. 2015. Profil Lipoprotein Tikus dalam Kondisi Hiperglikemia. Fakultas Kedoteran Hewan Universitas Udayana. Bali. 
Nur, K. 2013. Karakterisasi Simplisi dan Standarisasi Ektrak Etanol Herba Kemangi (Ocimum mericanum L.) Fakultas Kedoktean dan Ilmu Kesehatan Program Studi Farmasi. Jakarta.

Anas, B., dan Harry, B.S. 2016. Buku Tumbuhan Liar Berkhasiat Obat. Forda Press. Jawa Barat.

Eva, Z., Nurdin, R., dan Supriadi. 2017. Pengaruh Pemberian Ekstrak Buah Kelor (Moringa oleifera) Terhadap Penurunan Kadar Kolesterol Pada Darah Hewan Mencit (Mus musculus). Universitas Tadaluko. Palu

Ma'rufi, R., dan Rosita, L. 2014. Hubungan Dislipidemia dan Kejadian Penyakit Jantung Koroner.Departemen

Patologi Klinik, Fakultas Kedokteran Universitas Islam Indonesia. Yogyakarta.

Ni Kadek, W., dan Ni Made, P.S. 2014. Uji Antihiperlipidemia Fraksi Saponin Daun Katuk (Sauropus androgynus (L.) Merr) dan Mekanisme Aktivitasnya Pada Tikus Jantan yang diinduksi Hiperlipidemia. Universitas Udayana. Jimbaran. 